Digital Press Social Sciences and Humanities

Tourist Preferences in Choosing Nomadic Tourism-Based Accommodation in Bandung Regency

Priscilla Jessica J. Josary, Anisha Rahma Shilfa, Rayhan Masagi and Rindiani Sephia

Proceeding of Indonesia Heritage Tourism Forum 2019 (IHTF 2019)

Dewi Pratika Ayu Dhira Pradati (eds) 


\title{
Tourist Preferences in Choosing Nomadic Tourism-Based Accommodation in Bandung Regency
}

\author{
Priscilla Jessica J. Josary*, Anisha Rahma Shilfa, Rayhan Masagi, and Rindiani Sephia \\ Travel Industry Study, NHI Tourism Institute, Bandung, Indonesia \\ *e-mail: jessicajosary@gmail.com
}

\begin{abstract}
Nomadic tourism is a new tourism trend in Indonesia which is being proposed by the Ministry of Tourism. One of the destinations that provides nomadic tourism-based accommodation is Bandung Regency, Ciwidey District, and Rancabali District. This research focuses on tourist preferences in choosing nomadic tourism-based accommodation in Bandung Regency through cultural, social, personal, and psychological factors. This study uses a quantitative descriptive approach. The primary data of the study were obtained from 183 questionnaires distributed to tourists who were camping or staying in glamping in five locations namely Rancaupas, Ciwidey Valley resorts, Hejo Forest, Legok Kondang Lodge, Glamping Lakeside Rancabali. The measurement scale used is the Likert scale. This study resulted in that the four preference factors were equally important for tourists in choosing nomadic tourism-based accommodation in Bandung Regency.
\end{abstract}

\section{Keywords}

accommodation, nomadic tourism, preference factor, tourist preference

\section{Introduction}

There are several types of tourism that can attract tourists' attention to a tourist destination such as Digital Tourism, Smart Tourism, and Nomadic Tourism. The Ministry of Tourism carries a new program called Nomadic Tourism. Nomadic Tourism is a new tourist style where tourists can settle in a certain period of time in a tourist destination with portable and transferable amenities (Asisten Deputi Manajemen Strategis - Kementerian Pariwisata Republik Indonesia, 2019). In its development, Nomadic Tourism consists of 3 components, namely: the attraction of nomads, nomadic facilities, and accessibility of nomads.

Nomadic Development Tourism has begun to spread in 34 provinces in Indonesia and one of them in Bandung Regency. The presence of Nomadic Tourism in Bandung Regency strongly supports the program carried out by the ministry. Providing nomadic-based accommodation in Ciwidey and Rancabali Subdistricts which are favorite destinations for tourists, such as Glamping Lakeside Rancabali in Rancabali, Ciwidey Valley Resort in Ciwidey, Legok Kondang Lodge in Lebakmuncang, Rancaupas Smart Camp at Rancabali, and Hejo Forest Resort. Consumer Behaviors are things that underlie consumers to make a purchase decision. Tourist behavior according to Hasan (2008) is a complex psychological response that arises in the form of behavior or specific behavior that is directly involved in the effort to obtain and use products and determine the making decision process in purchasing products including in making repeat purchases. Tourist behavior in choosing Nomadic Tourism based-accommodation relies on preference.

Preference is one of the tourist behaviors which becomes a benchmark in making a decision to choose options. Preference has four factors, such as culture, social, psychological, and personal (Setiadi, 2013). Then according to Kotler \& Keller (2009) explained that business people must know and understand the needs and desires of tourists in the form of services, ideas, and experiences that are able to satisfy tourists. According to Sudibyo (2002), states that measurement of consumer preferences is very important, because: as a basis for attracting consumers to buy products, as a reference for companies to implement consumer loyalty development programs, and to maintain ongoing interaction between consumers and companies. The purpose of this study is to study the most supportive factors in choosing Nomadic Tourism accommodation based on tourist preferences in Bandung Regency. Then the output of this research itself aims to provide input in the field of accommodation based on Nomadic Tourism to businesses and provide 
advice to travel agents in choosing targets to sell a tour package and can be used as a basis for the development of accommodation based on nomadic tourism.

\section{Methods}

This research uses a descriptive quantitative method. The quantitative method is used to examine certain populations or samples, data analysis is quantitative/statistical, with the aim to test the hypothesis that has been set (Sugiyono, 2015). Sugiyono (2012) describes the object of research as a shot chosen to obtain data with specific goals and uses regarding an objective, valid, and also reliable. The objects in this study are tourists who have stayed or are staying at the five research centers, such as tourists who have stayed or are staying at Glamping Lakeside Rancabali, Hejo Forest Resort, Rancaupas, Ciwidey Valley Resort, Legok Kondang Lodge. The research team chooses the five objects because these 5 attractions have more potential compared to other camping or glamping sites. Such as Glamping Lakeside Rancabali which has advantages on the lake and Pinishi restaurant, Hejo Forest Resort which provides glamping at a fairly cheap price, Rancaupas with a place that can accommodate many visitors, Ciwidey Valley Resort with a place close to the city of Ciwidey, and Legok Kondang lodge has an attractive natural landscape and has quite a lot of glamping compared to the others. Then the population of this study was the tourists who visited Bandung Regency with samples obtained which amounted to 183 respondents from 200 samples with 17 data respondents who were invalid. Data collection techniques used are by distributing questionnaires and documentation studies. Validity and Reliability Tests are carried out by using IBM SPSS Statistics 24 on 38 respondents who were sampled with 28 valid questions and 2 invalid questions and both invalid questions were discarded and the 28 questions were tested again. the results show all indicators of the question are valid.

In this study, the research team used descriptive statistical techniques as data analysis. Descriptive analysis is a series of procedures used to reduce and summarize data without losing important information or to educate data from variables that are converted into fewer variables (Supranto, 2010). Descriptive analysis is also used to find out what data can explain a problem. In the analysis of variance, multiple regression, and discriminant, one variable is called the dependent variable or criterion and the other variable is the independent variable or predictor. In factor analysis is called interdependence technique (interdependence technique) in which all sets of independent relationships are examined. Then, the research team calculated using a Likert Scale. Likert scale is used to measure the results of the data that has been obtained from the distribution of questionnaires. The results of the research respondent's questionnaires will be processed using a Likert scale. The value of each respondent's answer is as follows:

$\begin{array}{ll}\text { a. Strongly Disagree } & : 1 \\ \text { b. Disagree } & : 2 \\ \text { c. Neutral } & : 3 \\ \text { d. Agree } & : 4 \\ \text { e. Strongly Agree } & : 5\end{array}$

Before getting an interval value, you need to know the lowest value and the highest value using the following formula:

- Highest Score $=$ Total Respondents $\mathrm{x}$ Total Questions x Value Weight

- Lowest Score $=$ Total Respondents $\mathrm{x}$ Total Questions $\mathrm{x}$ Value Weight

- Range $=($ Highest score - Lowest score $) /$ Interval Class

After the questionnaire has been collected and calculated, the total weighted value of each indicator then the writer performs the calculation using the formula described above so that the calculation results of each dimension are obtained. 


\section{Findings and Discussion}

\subsection{Cultural Factors}

Table 1 Data analysis of cultural factors

\begin{tabular}{lll}
\hline & \multicolumn{2}{c}{ TOTAL } \\
\cline { 2 - 3 } Cultural Factors & Category \\
\hline Origin & 715 & A \\
Religion & 629 & A \\
Prating Room & 751 & A \\
Location & 768 & A \\
Weather & 768 & A \\
Local Lodging & 661 & A \\
Nationalism & 719 & A \\
Proud & 6374 & SA \\
Community Acceptance & 660 & S \\
\hline & 793 & \\
\hline
\end{tabular}

Note:

SA : Strongly Agree

A : Agree

$\mathrm{N}$ : Neutral

SD : Strongly Disagree

D : Disagree

The tourists consider their pride in camping or staying overnight in glamping. Tourists who have carried out these activities claim that they have their own pride because camping or staying in glamping is becoming a trend among young people, especially those aged 17-26. In addition to pride in the weather and location factors also become one of the things that count. The average tourists who come to Bandung Regency to do camping activities or stay in glamping are tourists whose native weather (Jakarta) is hotter so they decide to look for a new atmosphere with cool nature and its location that is easy to reach. Tourists also consider in terms of religion in determining the place where they will stay because there are some restrictions in each religion that must be shunned if there are things that are prohibited. Likewise with the ease of places of worship. Many tourists agree that it is easy to worship while camping or staying in glamping. In addition to avoiding the prohibitions in religion, they must also perform worship at the time specified by their religion. After tourists camping or staying overnight in glamping, tourists will feel recognized in their environment because they have camped or stayed in glamping which is not done too much by others. Tourists admit if they increasingly love the area and homeland after camping or staying in glamping because they realize that the area has a natural state that is not yet possible in other cities or in other countries. Out of love for the region and the motherland, tourists also agree to choose the accommodation that is processed by local residents because they help the local residents who have local lodging there. 


\subsection{Social Factors}

Table 2 Data analysis of social factors

\begin{tabular}{lcc}
\hline \multirow{2}{*}{ Social Factors } & \multicolumn{2}{c}{ TOTAL } \\
\cline { 2 - 3 } & $\mathrm{fx}$ & Category \\
\hline Media Internet & 730 & $\mathrm{~A}$ \\
Glamping suitable for & 775 & $\mathrm{SA}$ \\
stay & 809 & $\mathrm{SA}$ \\
Familiarity & 569 & $\mathrm{~N}$ \\
Position & & $\mathrm{N}$ \\
Prestige & 565 & $\mathrm{~A}$ \\
\hline
\end{tabular}

Familiarity is one of the main factors of tourists in deciding to stay in glamping or camping activities such as during the tent-making process together which can build familiarity with one another, as well as the factor of staying in glamping and camping which have sufficient capacity of one room big that causes a togetherness. No wonder familiarity is one of the determinants of tourists in deciding whether to camp or stay overnight in glamping. Besides glamping or camping, facilities that are sufficient to make glamping or camping become one of the suitable accommodations in addition to hotels or resorts as well as the support of internet media that makes it easy for tourists to find information about the place they are going to in Bandung Regency. Tourists are not too concerned with prestige and position in choosing locations for camping or glamping. From the data obtained from the tourists, it is more concerned with comfort compared to prestige and position in choosing accommodation based on nomadic tourism.

\subsection{Psychological Factors}

Table 3 Data analysis of psychological factors

\begin{tabular}{|c|c|c|}
\hline \multirow{2}{*}{ Psychological Factors } & \multicolumn{2}{|c|}{ TOTAL } \\
\hline & $f x$ & Category \\
\hline Out of Rutinity & 753 & A \\
\hline Introduce Glamping & 748 & A \\
\hline Tell about Experience & 714 & A \\
\hline $\begin{array}{l}\text { Purpose equal to } \\
\text { Expectation }\end{array}$ & 830 & SA \\
\hline $\begin{array}{l}\text { Purpose equal to } \\
\text { realization }\end{array}$ & 718 & A \\
\hline & 3763 & A \\
\hline
\end{tabular}


Expectations become one of the main factors in choosing accommodation based on nomadic tourism in Bandung Regency because tourists get the reality that is in accordance with what they had previously imagined regarding camping activities or staying in glamping. Besides that, getting out of the daily routine is also a supporting factor for tourists in deciding to do camping activities or stay overnight in glamping by looking for a new atmosphere and cool nature so that it will make tourists feel comfortable and get peace. This will make tourists introduce camping activities or stay overnight at the glamping to those closest to them such as giving news when friends, work relatives, and family need a reference to a new vacation spot. They will also tell and share their experiences on various media, especially social media such as Instagram, Whatsapp, Youtube, and Facebook, which are widely used by millennials today.

\subsection{Personal Factors}

Table 4 Data analysis of personal factors

\begin{tabular}{lcc}
\hline \multirow{2}{*}{ Personal Factors } & \multicolumn{2}{c}{ TOTAL } \\
\cline { 2 - 3 } & $\mathrm{fx}$ & Category \\
\hline Age & 610 & $\mathrm{~N}$ \\
Work & 570 & $\mathrm{~N}$ \\
Trend & 600 & $\mathrm{~N}$ \\
Repeater & 786 & $\mathrm{SA}$ \\
\hline & 2566 & $\mathrm{~A}$ \\
\hline
\end{tabular}

In camping or staying overnight at the glamping, tourists have gained a variety of experiences that might not have been obtained before. The experience is very suitable for activities among young people, who can foster a sense of togetherness, intimacy, and atmosphere that makes tourists feel entertained and makes tourists want to return to camping or stay overnight in glamping. Moreover, in general glamping or camping accommodation providers complement facilities for outbound activities. In addition, in personal factors, tourists are not too concerned with age, occupation, or trends in choosing accommodation based on nomadic tourism. Age and occupation do not become a benchmark for someone to choose accommodation based on nomadic tourism as long as the person likes outdoor activities. If tourists are able and like to do camping activities or stay overnight in the glamping, tourists will repeat doing these activities. Although nomadic tourism is becoming a trend that is used by the ministry of tourism as a way of visiting tourists for data to Indonesia, it turns out that the trend is not something that is thought by tourists who are camping or staying in glamping. Tourists choose camping or staying at glamping because they get new experiences while he is camping or staying at glamping and also familiarity with friends, family, and coworkers while camping and staying at glamping. 
Preference for choosing priorities based on nomadic tourism which has been done through the four factors mentioned above are the factor of cultural factors, social factors, psychological factors, and personal factors with the following results:

Table 5 Overall Analysis of Tourist Preference Factors

\begin{tabular}{lcc}
\hline & \multicolumn{2}{c}{ TOTAL } \\
\cline { 2 - 3 } Preference & $\mathrm{fx}$ & Category \\
\hline Cultural Factors & 6374 & $\mathrm{~A}$ \\
Social Factors & 3621 & $\mathrm{~A}$ \\
Psychological Factors & 3763 & $\mathrm{~A}$ \\
Personal Factors & 2566 & A \\
\hline
\end{tabular}

It can be concluded that way because these factors are equally important for tourists in deciding a decision to go camping or stay at glamping with an acceptable average of 708.2 cultural factors, social factors 724.2 , psychological factors 752.6, and personal factors 641.5. From these four personal factors, the most popular is the psychological factors related to camping or staying in glamping reports, with values an average value of 752.6 from 3763 because expectations are one of the main indicators that dominate in choosing accommodation based on tourism nomads in Bandung Regency with the reason tourists get the reality that corresponds to more than what they previously thought about camping activities or staying in glamping. Besides, out of the daily routine is also a supporting factor for tourists in deciding to do new camping activities and natural cool so will make tourists feel comfortable and get peace. This will make tourists announce camping activities or stay at the glamping to those closest to them such as giving news when friends, work relatives, and family need a reference to a new vacation spot. They will also tell and share their experiences in various media, especially social media such as Instagram, Whatsapp, Youtube, and Facebook, which are widely used by millennials today. Camping or overnight activities at Glamping provide a memorable new experience to make tourists satisfied and will do the activity again and become a repeater tourist.

\section{Conclusion}

Based on the presentation of data from the results of the research and discussion of tourist preferences in choosing accommodation based on nomadic tourism in Bandung Regency, it can be concluded as follows: (1) In the cultural factor, pride becomes a very consideration for tourists in determining a decision to stay in glamping or camping, the sense of pride has the highest score of 793 out of the total value of 6374 , tourists feel proud when staying in camping or glamping because currently, nomadic tourism is a new tourism trend in Indonesia. (2) There are two indicators that are very influential for tourists in camping or staying overnight in glamping on social factors such as tourists strongly agree that glamping or camping is suitable to be a place to stay together with a total of 958, and staying overnight or camping will build a familiarity with a total of 809 . Glamping or camping itself has the capacity in one room large enough so that it is suitable for staying together building a friendship with each other such as for example tourists who camp somewhere will do building activities a tent, a bonfire, and events that can be done together so as to create togetherness and create intimacy. (3) On the psychological factors of tourists who have done camping or staying at glamping states that the expectations they want in glamping or camping are the same as the reality they get when camping or staying overnight at glamping so that tourists feel satisfied and happy because of what they hope it has been fulfilled well. Evidenced by getting the highest score of 830 out of a total of 3763 then followed by going out of the routine and choosing to do camping or stay overnight in glamping with a score of 753. (4) Then in the personal factor, the repeater leads with the highest score of 786 out of a total of 2566 which means that tourists are satisfied and will stay back in glamping or camping activities because tourists feel comfortable and have had a pleasant new experience. 
The suggestions of this research are: (a) as input for camping and glamping businesses in Bandung Regency to pay attention to the four factors of preference, especially the most prominent factors, (b) paying attention to cleanliness in the camping and glamping areas, especially in Rancaupas because of the large number of tourists visiting the place but the trash is still small, (c) as input for camping and glamping businesses to hold a Team Building program to attract more tourists to come, (d) complement the artificial tourist attractions as an additional attraction so that tourists do not feel bored while doing camping activities or staying in glamping, (e) improving service quality in every camping and glamping location.

\section{References}

Asisten Deputi Manajemen Strategis - Kementerian Pariwisata Republik Indonesia. (2019, February). Nomadic Tourism. Retrieved February 12, 2019, from http://eperformance.kemenpar.go.id/dokumen/4Nomadic

Hasan, A. (2008). Manajemen Pemasaran dan Marketing. Bandung: CV. Alfabeta.

Kotler, P., \& Keller, K. (2009). Manajemen Pemasaran. Edisi Ketiga Belas. Jakarta: Erlangga.

Setiadi. (2013). Perilaku Konsumen (edisi revisi). Jakarta: Kencana Perdana Media Grup.

Sudibyo. (2002). Perilaku Konsumen dan Kesinambungan Kebutuhan. Jakarta: PT Gramedia Pustaka Utama.

Sugiyono. (2012). Metode Penelitian Kuantitatif, Kualitatif dan R \& D. Bandung: Alfabeta.

Sugiyono. (2015). Metode penelitian pendidikan (pendekatan kuantitatif, kualitatif dan R\&D). Penerbit CV. Bandung: Alfabeta.

Supranto, J. (2010). Statistik Teori dan Aplikasi. Jakarta: UI Press. 